\title{
Erzincan Mengücek \\ Gazi Eğitim ve Araştırma Hastanesi'nde 2010-2018 Yılları Arasında Tanı Alan Erişkin Çölyak Hastalarının Değerlendirilmesi
}

Evaluation of Adult Celiac Patients Diagnosed in Erzincan Mengücek Gazi Training and Research Hospital Between 2010 and 2018

Mahir Tayfur
Erzincan Binali Yildırım Üniversitesi, Tip Fakültesi, Mengücek Gazi Eğitim ve Araştırma Hastanesi, Patoloji Bölümü, Erzincan, Türkiye

Yazışma Adresi / Correspondence:

Mahir Tayfur

Mengücek Gazi Eğitim ve Araştırma Hastanesi, Patoloji Bölümü, Başbağlar Mh., Hac1 Ali Akın Cd. No:32, 24100, Erzincan,Türkiye

T: $+905052104075 \quad$ E-mail: : drmahirtayfur@gmail.com

Geliş Tarihi / Received : 16.10.2019 Kabul Tarihi / Accepted : 24.01.2020

Orcid :

Mahir Tayfur https://orcid.org/0000-0001-7137-5465

( Sakarya Tip Dergisi / Sakarya Med J 2020, 10(1):37-43) Doi: Doi: 10.31832/smj.634047

\footnotetext{
Öz

Amaç Erzincan Mengücek Gazi Eğitim ve Araștırma Hastanesỉnde 2010-2018 yılları arasında tanı alan 18 yaș üstü erişkin Çölyak hastalarını değerlendirmek.

Gereç ve Klinik endikasyon sebebiyle hastanede duodenum biyopsisi yapılan 652 hastadan Çölyak hastalığı bulguları izlenen ve hastaneden Çölyak hastalığı raporu alan 54 erişkin Yöntemler hasta retrospektif olarak çalışmaya dahil edildi. Patoloji laboratuarımızın arşivinde bulunan doku gömülü parafin bloklardan 4 mikron kalınlığında kesitler alındı. Bu kesitler Hematoksilen-Eozin boyası ile boyanarak patoloji preparatları hazırlandı ve Modifiye Marsh-Oberhuber sınıflaması kullanılarak değerlendirildi.

Bulgular Calıșmamızda 54 hastanın 36'sı (\%66,66) kadın, 18’i (\%33,33) erkekti. Yaș aralığı 18-65 idi. Bu aralık kadınlarda 18-59, erkeklerde 18-65 idi. Yaș ortalaması 39,48 olup kadınlarda 36,80, erkeklerde 44,83 idi. Hastaların 2'sinde (\%3,70) evre 1, 5'inde $(\% 9,25)$ evre 2, 9'unda (\%16,66) evre 3a, 34'ünde (\%62,90) evre 3b ve 4'ünde (\%7,40) evre 3c izlendi. Hastalarda evre 4 izlenmedi.

Sonuç Çölyak hastalığının erken teşhisinin ve uygun tedavisinin hayat kalitesini artıracağından dolayı, özellikle sebebi belirlenemeyen malabsorbsiyon bulguları gibi gastrointestinal sistem ve ağrı bașta olmak üzere gastrointestinal sistem dıșı șikayetleri olan hastalarda bu șikayetlerin arkasında Çölyak hastalığının bulunabileceğinin göz ardı edilmemesi gerekir.

Anahtar Çölyak Hastalı̆ı̆; Gluten Enteropati; Duodenum

Kelimeler

Abstract

Objective The aim of this study was to evaluate adult Celiac patients diagnosed in Erzincan Mengücek Gazi Training and Research Hospital between $2010-2018$.

Materials Fifty-four adult patients who had Celiac disease findings from 652 patients who underwent duodenal biopsy in the hospital for clinical indication and who received a Celiac disease report from and Methods the hospital were included in the study retrospectively. 4 micron thick sections were taken from tissue embedded parafin blocks in the archives of our pathology laboratory. These sections were stained with Hematoxylin-Eosin stain and pathology preparations were prepared and evaluated using Modified Marsh-Oberhuber classification.

Results In this study, $36(66.66 \%)$ of the 54 patients were female and 18 (33.33\%) were male. The age range was 18-65 years. This range was $18-59$ in women and $18-65$ in men. The mean age was 39.48 and it was 36.80 in women and 44.83 in men. Type 1 was observed in 2 patients (3.70\%), type 2 was observed in 5 patients (9.25\%), type 3a was observed in 9 patients (16.66\%), type $3 b$ was observed in 34 patients (62.90\%), and type $3 \mathrm{c}$ was observed in 4 patients (7.40\%). Type 4 was not observed in the patients.

Conclusion Because of early diagnosis and appropriate treatment of Celiac disease will improve quality of life, it should not be ignored that Celiac disease may be present behind these complaints, especially in patients with gastrointestinal complaints such as malabsorption symptoms and non-gastrointestinal complaints such as pain of unknown cause.

Keywords Celiac Disease; Gluten Enteropathy; Duodenum
} 


\section{Giriş}

Çölyak hastalığı (gluten duyarlı enteropati, çölyak sprue), gluten adlı proteine karşı, genetik hassasiyeti olan kişilerin ince bağırsak mukozasında görülen otoimmün bir bozukluktur. Bu kişilerde ömür boyu süren ve kronikleşen inflamatuar bir hasar meydana gelir. Gluten özellikle arpa, buğday, çavdar, yulaf gibi tahıllarda bulunurken misır, pirinç, soya, bezelye gibi besin maddelerinde bulunmaz. Gluten otoimmun reaksiyon sonucu yıllar içerisinde ince bağırsakta villus atrofisine sebebiyet verir. Bunun sonucunda mukozada emilim yüzeyi zamanla azalır. Vücuda alınan besinler atrofik villuslar tarafindan yeterince emilemez ve beslenme bozukluğu görülür. ${ }^{1-4}$ Duodenumda normalde, mukozada villus/kript oranı 3-5/1 dir. Çölyak hastalığında bu oran, hastalığın evresi ilerledikçe, gelişen villus atrofisine bağlı olarak belirgin derecede azalır. ${ }^{5}$ Ayrıca evre ilerledikçe özellikle primer olarak barsakta yerleşimli non-Hodgkin lenfoma gibi malignitelerin görülmesi artış göstermektedir. ${ }^{6}$ Çölyak hastalığı genellikle diyare, yağlı dışkı, kilo kaybı, şişkinlik, karın ağrısı gibi gastrointestinal sistem belirtileri ile ortaya çıkar. ${ }^{2,7}$ Gastrointestinal sistem dışı belirtiler de görülür. Bunların arasında karaciğer fonksiyon testlerinde anormallik, demir eksikliği anemisi, kemik hastalıkları, otoimmun tiriodit, dermatitis herpetiformis gibi cilt hastalıkları, nörolojik bozukluklar vb. bulunur. ${ }^{2}$

Çölyak hastalığı insanların cinsiyetine, yaşına, genetik özelliklerine, yaşadıkları bölgeye ve çevre faktörlerine bağlı olduğundan hastalığın sıklığında toplumlara ve bölgelere göre değişiklikler görülür. ${ }^{89}$ Kadın erkek oranı 2,80:1'dir. ${ }^{10}$ 20-25 yaş grubu için kadın erkek oranı 5,60: 1'dir. Bu oran, hayat boyu 35-40 yaşları için 2,53: 1 ve 85-90 bantları için 1.25: 1 olarak düşmektedir. Kadınlarda en fazla sayıda teşhis $35-45$ yaş arasında konulur. ${ }^{11}$

Çölyak hastalığında prevalans dünya genelinde \% 0,50-1 olup son zamanlarda artış göstermektedir., ${ }^{2,9,12}$ Batı toplumlarındaki prevalansı 0,40-1,30 arasında olup Türkiye'deki prevalansı ise \%1,30 olarak bulunmuştur. ${ }^{13,14}$ Preva- lans, akrabalarda daha yüksek olarak görülmekte olup kız kardeşlerde $\% 17,60$, erkek kardeşlerde $\% 10,80$ ve ebeveynlerde $\%$ 3,40 daha fazla görülmektedir. ${ }^{12}$

Çölyak hastalığı olan birçok kişide klinik belirti görülmeyebilir. Çölyak hastalığında klinik kişiden kişiye değişiklik gösterebilir. Belirtilerin atipik olmasından dolayı genelde Çölyak hastalığı akla getirilmez ve öncelikle diğer hastalıklar düşünülür. Bu da gereksiz araştırmaya, yanlış teşhise, uygun olmayan ve gereksiz tedavilere sebep olur. Çölyak hastalığında belirtilerin başlamasından teşhis anına kadar geçen süre ortalaması 2,5 yıl olarak bulunmuştur. ${ }^{2,3}$

Diyette gluten mevcut olmadığı sürece Çölyak hastalığı ortaya çıkmaz. Çölyak hastalığı özellikle Avusturalya, Yeni Zelanda ve Ortadoğu gibi fazla tahıl tüketilen bölgelerde sık görülürken, Uzakdoğu gibi tahıl tüketiminin neredeyse olmadığı bölgelerde görülmediği varsayılır. ${ }^{15}$ Çölyak hastalığının buralarda görülmemesinin sebebi bu bölgelerde tahıl tüketiminin olmaması olup Çölyak hastalığına yatkın olan kişiler tahıl ürünlerinin kullanıldığı bölgelere gittiklerinde Çölyak hastalığı şikayetleri görülmeye başlar. Amerika Birleşik Devletlerinde ise ilginç olarak beyaz halkın fazlalığına rağmen göreceli olarak çok daha az olarak görülür. ${ }^{16}$

Çölyak hastalığ́ genellikle Çölyak spesifik antikorların serolojik testi ile tespit edilir. Doku transglutaminaz IgA ve antiendomisyum IgA testleri yüksek spesifite ve sensitiviteye sahiptir., ${ }^{2,17,18}$ Kalıcı pozitif seroloji genellikle devam eden bağırsak hasarını ve glütene maruz kalmayı gösterir. Serolojik testler teşhisten 6 ve 12 ay sonra yapılmalıdır. ${ }^{19}$ Kesin teşhis ise duodenum mukozasından yapılan biyopsi ile konur. ${ }^{2}$

Çölyak hastalığı, esas olarak DQ2 ve DQ8 sınıflarından HLA-II antijenlerini kodlayan genlerle yakından ilişkilidir. Genel popülasyonun yaklaşık \%40'1 HLA-DQ2 veya HLA-DQ8 markerlerine sahip olmasına rağmen, Çölyak hastalarında bu oran \%90-95'lerdedir. ${ }^{20,21}$ 
Glutenin diyetten çıkarılması tedavi sürecindeki en önemli basamağ1 oluşturur. Buğday, arpa, çavdar ve yulaf yerine mısır, pirinç, karabuğday ile beslenme sağlanır. Hastaların düzgün şekilde eğitimi, psikolojik destek verilmesi ve diyete uyup uymadıklarının düzenli takibi gereklidir. Gluten içermeyen diyet uygulanmasıyla atrofiye uğramış ince bağırsak mukozası tekrar normal şekline döner ve normal fonksiyonunu geri kazanır. ${ }^{2,22}$ Histolojik remisyon genellikle çocuklarda komplettir, ancak erişkinlerde iyileşme daha yavaş ve sıklıkla inkomplettir. ${ }^{23}$

Çölyak hastalığında farklı histopatolojik sınıflamalar kullanılır. Bunlar Marsh (1992), Modifiye Marsh-Oberhuber (1999), Corazza-Villanacci (2005), Ensari (2012), Taavela (2013) sinıflamalarıdır. ${ }^{24-28}$ Son zamanlarda Marsh ve ark. yıllar içerisinde kendi sınıflamalarının daha anlaşılır hale gelmesi için güncelleme çalışmalarını devam ettirmektedirler. $^{29}$

$\mathrm{Bu}$ çalışma, Erzincan Mengücek Gazi Eğitim ve Araştırma Hastanesi'nde 01/01/2010-31/12/2018 tarihleri arasinda erişkin Çölyak hastalarını değerlendirip histopatolojik sınıflamasını ortaya koymak amacıyla yapılmış olup bu alanda yapılacak çalışmalara da katkıda bulunacağı düşünülmektedir.

\section{Gereç ve Yöntemler}

Yapılacak çalışma için Erzincan Binali Yıldırım Üniversitesi Klinik Araştırmalar Etik Kurul Başkanlığının 26/03/2019 tarih ve 01 sayılı oturumunda 01/16 sayılı kararı ile etik kurul onayı alındı. Çalışmaya dahil edilen hastalardan bilgilendirilmiş onam formu alındı. 2010-2018 yılları arasında Erzincan Mengücek Gazi Eğitim ve Araştırma Hastanesi'ne başvuran ve klinik endikasyon sebebiyle duodenum biyopsisi yapılan 652 hastanın duodenum biyopsileri incelendi. Çölyak spesifik antikorları yüksek olan, duodenum biyopsileri sonucu Çölyak hastalığı bulguları izlenen ve hastaneden Çölyak hastalığı raporu alan 54 erişkin hasta retrospektif olarak çalışmaya dahil edildi. Patoloji laboratuarımızın arşivinde bulunan doku gömülü parafin bloklardan 4 mikron kalınlığında kesitler alındı. $\mathrm{Bu}$ kesitler Hematoksilen-Eozin boyası ile boyanarak patoloji preparatları hazırlandı ve Olympus Cx41 ışık mikroskobu ile incelendi. Duodenuma ait biyopsi örnekleri, Çölyak hastalığında farklı sınıflamalar kullanılmakla birlikte, özellikle 3. evrede histopatolojik olarak daha ayrıntılı incelemeye imkan verdiği için Modifiye Marsh-Oberhuber sınıflaması kullanılarak değerlendirildi. ${ }^{25}$

Modifiye Marsh-Oberhuber sinıflamasına göre Evre 0: İntraepitelyal lenfosit (İEL) artışı, <30/100 Epitelyal hücre (EH); Evre 1: >30/100 EH İEL, normal villus ve kriptler; Evre 2: >30/100 EH İEL, kript hiperplazisi, normal villuslar; Evre 3a: >30/100 EH İEL, villuslarda hafif düzleşme, kript hiperplazisi; Evre 3b: >30/100 EH İEL, villuslarda orta düzeyde düzleşme, kript hiperplazisi; Evre 3c: $>30 / 100$ EH İEL, total villus düzleşmesi, kript hiperplazisi; Evre 4: Hipoplazi yi içerir. İntraepitelyal lenfosit sayısında artış için kriter duodenum için 30, jejunum için 40 olarak uygulanır. ${ }^{3,25}$

Tüm bağımsız ve sonuç değişkenleri için tanımlayıcı özet istatistikler elde edildi. İstatistiksel olarak anlamlı olan p değerinin 0,05'den küçük olduğu kabul edildi. İstatistiksel analiz SPSS istatistik yazılımı (Windows için IBM SPSS Statistic, Sürüm 20.0; IBM Corp., Armonk, NY, ABD) kullanılarak yapıldi.

\section{Bulgular}

Çalışmamızda 54 hastanın 36'sı $(\% 66,66)$ kadın, 18’i $(\% 33,33)$ erkekti. Yaş aralığı 18-65 idi. Bu aralık kadınlarda 18-59, erkeklerde 18-65 idi. Yaş ortalaması 39,48 olup kadınlarda 36,80, erkeklerde 44,83 idi. Çölyak hastalığı incelemesinde, hastaların duodenumundan alınan doku örnekleri, sağlıklı bir kişinin duodenum mukozasındaki villuslar ve kriptler ile kıyaslanarak değerlendirildi. (Şekil 1A). Bu çalışmada, hastaların 2'sinde $(\% 3,70)$ evre 1 (Şekil 1B), 5'inde $(\% 9,25)$ evre 2 (Şekil2A), 9’unda $(\% 16,66)$ evre 3a (Şekil 2B), 34'ünde (\%62,90) evre 3b (Şekil 3A), 4 'ünde $(\% 7,40)$ evre 3c (Şekil 3B) izlendi. Hastalarda evre 
4 izlenmedi.

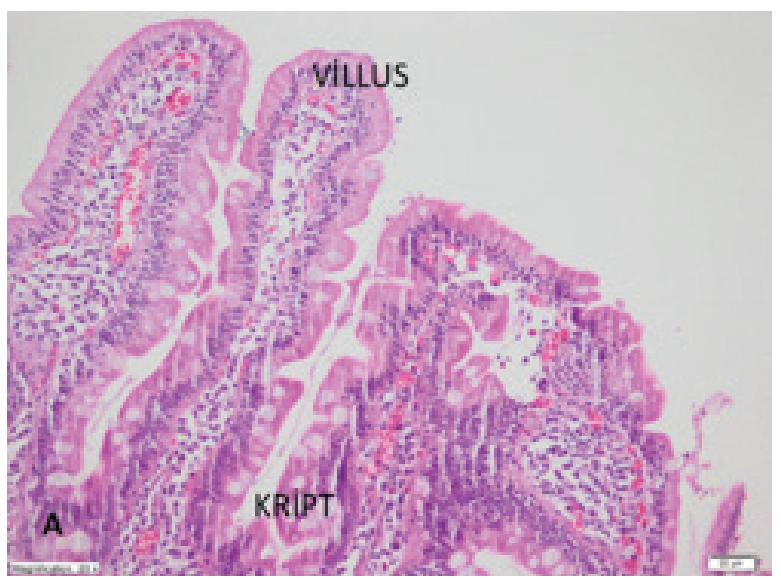

Şekil1A. ModifiyeMarsh-Oberhuber sınıflaması Evre 0. Săglıklı bir kişinin duodenum mukozasında izlenen normalyapıdaki villus ve kriptler. Intraepitelyal lenfosit sayısı (IEL) $30>/ 100$.

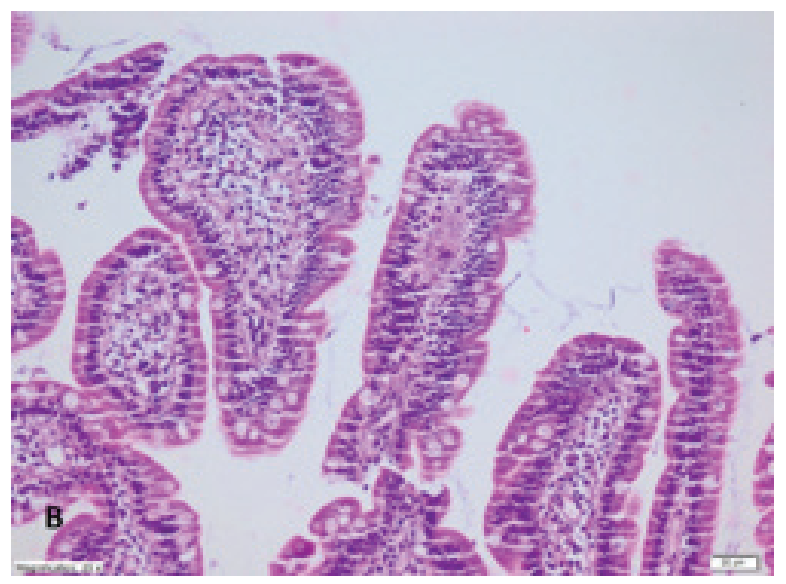

Şekil1B. Evre 1. Normal villus ve kriptler. İEL $30</ 100$. (HEx200)

Evre 1 izlenen hastalardan 2 hastanın 2'si de (\%100) kadın olup yaş ortalaması 46 idi. Evre 2 izlenen hastalarda erkek oranı 3/5 (\%60) ve kadın oranı 2/5 (\%40) olup yaş ortalaması sırasiyla 42,3 ve 26 idi. Evre 3a izlenen hastalarda erkek oranı 5/9 $(\% 55,60)$ ve kadın oranı 4/9 (\%44,40) olup yaş ortalaması sırasıyla 57,2 ve 28,25 idi. Evre 3 b izlenen hastalarda erkek oranı $8 / 34(\% 23,50)$ ve kadın oranı $26 / 34$ (\%66) olup yaş ortalaması sırasıyla 26,86 ve 39,42 idi. Evre
$3 c$ izlenen hastalarda erkek oranı 2/4 (\%50) ve kadın oranı 2/4 (\%50) olup yaş ortalaması sırasıyla 49,5 ve 34,5 idi. (Grafik 1,2)

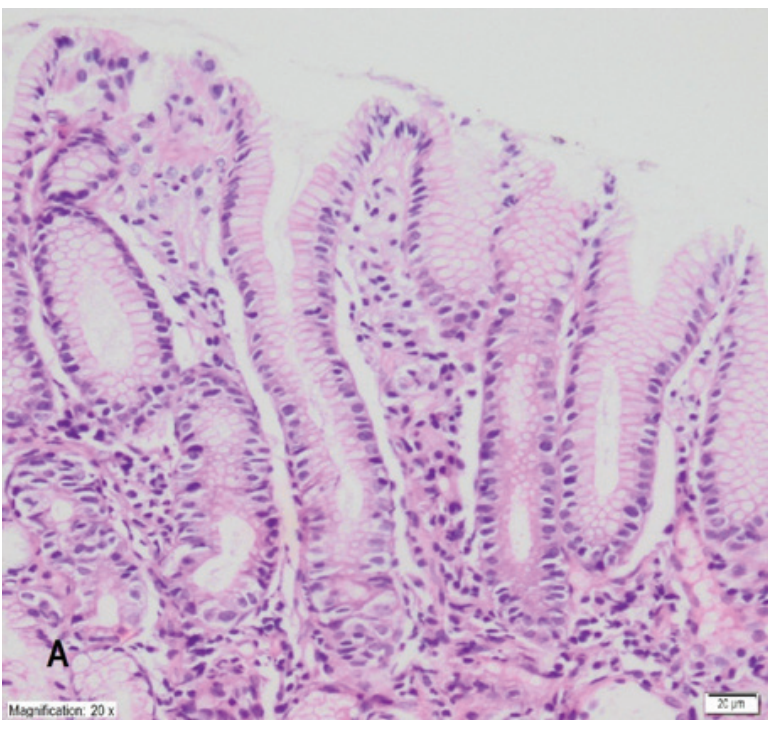

Şekil 2A. Evre 2. Normal villuslar, hiperplazik kriptler. İEL $30</ 100$. (HEx200)

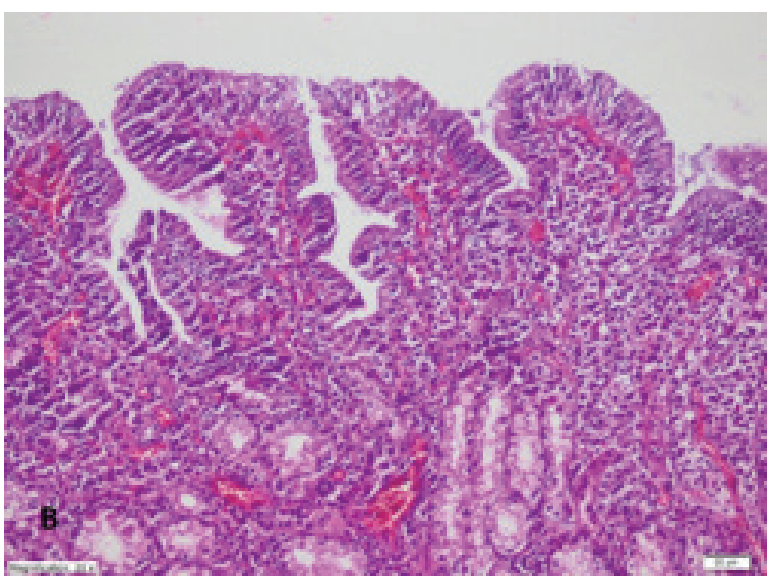

Şekil2B.Evre 3A. Villuslarda hafif düzleşme ve genişleme, hiperplazik kriptler. IEL 30</100. (HEx200) 


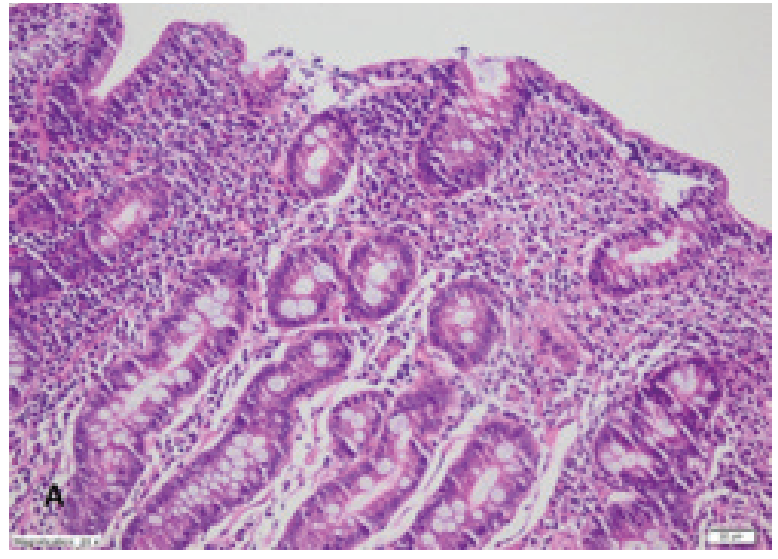

Şekil 3A. Evre 3B. Villuslarda orta düzeyde düzleşme, hiperplazik kriptler. IEL 30</100.(HEx200)

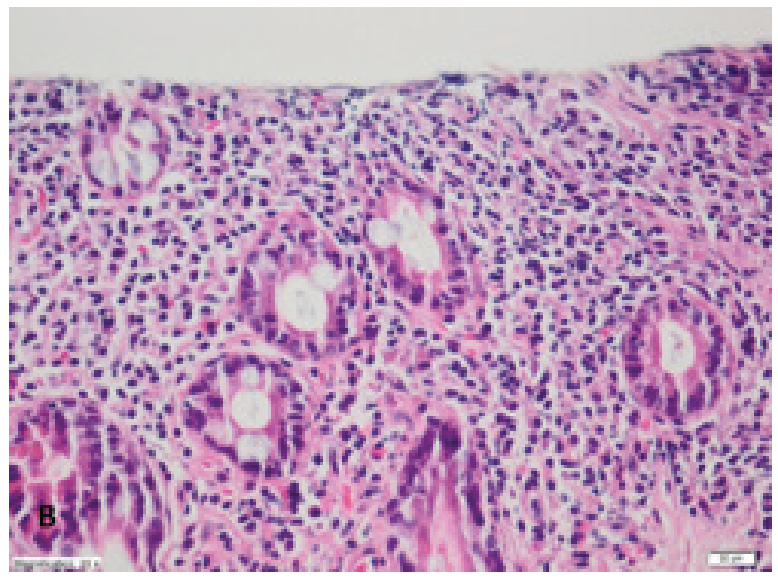

Şekil 3B. Evre 3C. Total villus düzleşmesi, hiperplazik kriptler. İEL $30</ 100$. (HEx200)

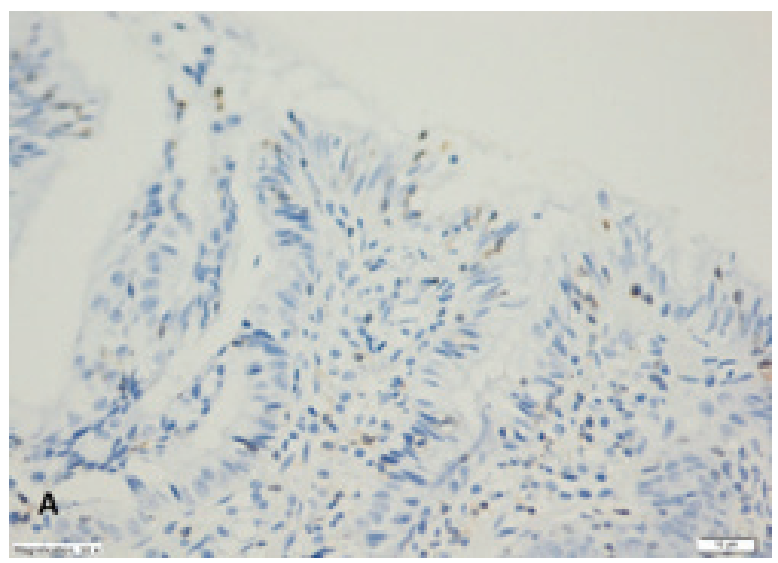

Şekil 4A. CD3 uygulamasının karşılaştırılması. Normal duodenum mukozasinda seyrek lenfosit (Evre0). (x400)

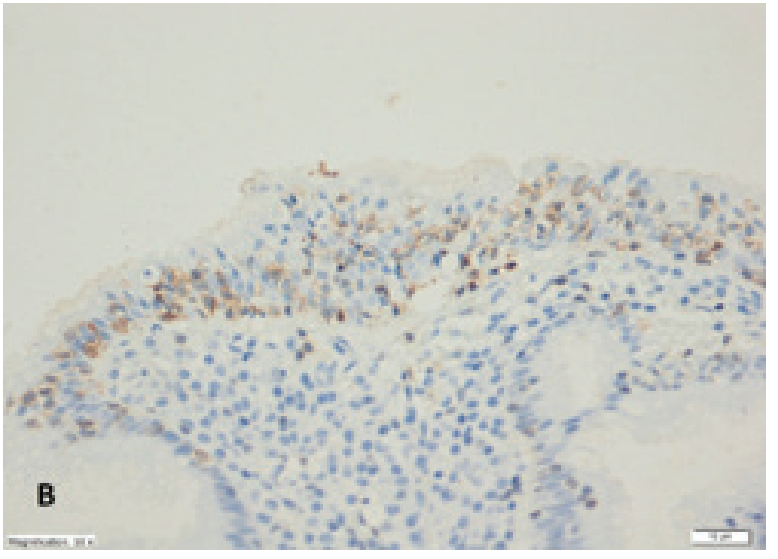

Şekil4B. Çölyak Evre 3B'de \%30'un üzerinde intraepitelyal lenfosit. (x400)

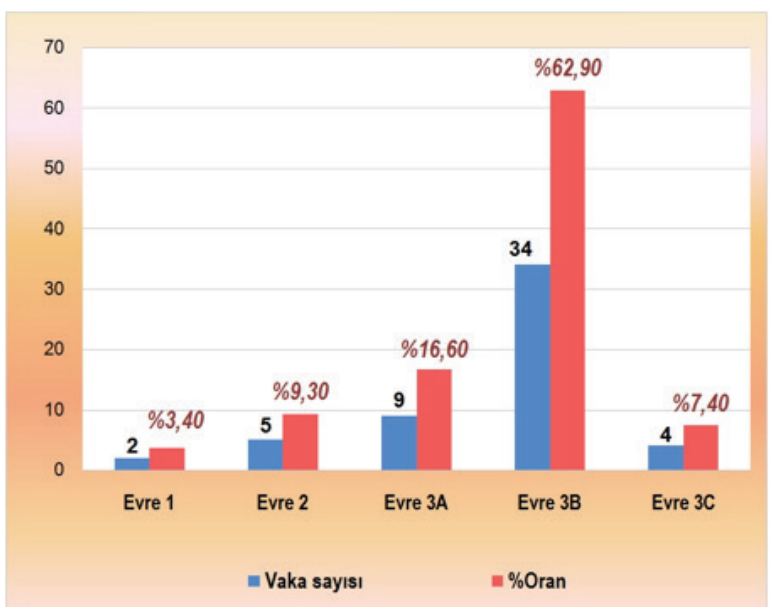

Grafik 1. Modifiye Marsh-Oberhuber sinıflamasına göre Çölyak hastalarının evrelere göre dağılımı.

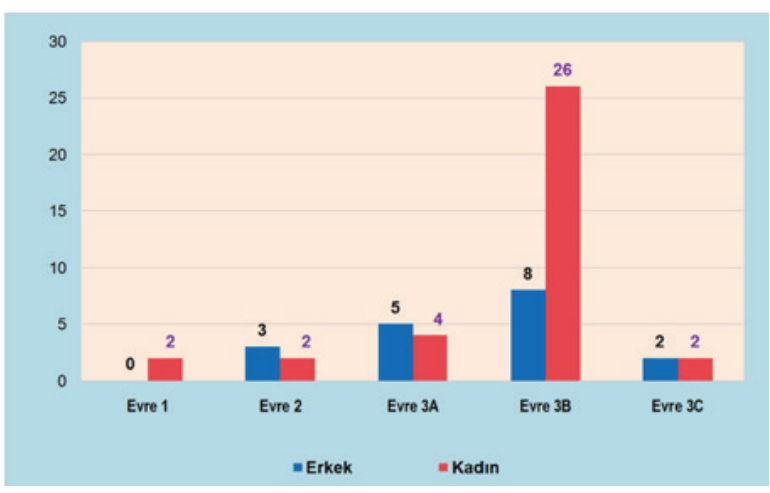

Grafik 2. Çölyak hastalarında evrelere göre cinsiyet dağılımı. 


\section{TARTIŞMA}

Çalışmamızda hastaların 36’sı $(\% 66,66)$ kadın, 18'i $(\% 33,33)$ erkekti. Yaş aralığı 18-65 idi. Bu aralık kadınlarda 18-59, erkeklerde 18-65 idi. Yaş ortalaması 39,48 olup kadınlarda 36,80, erkeklerde 44,83 olarak bulundu. Karaahmet'in 113 vakalık çalışmasında hasta yaşaralığı 16-73 idi. Yaş ortalaması 36,83 olup kadınlarda 34,9, erkeklerde 40,8 idi. Hastaların 77'si $(\% 68,14)$ kadın, 36'sı $(\% 31,86)$ erkek olup yaş ortalaması 36,83 idi. ${ }^{3}$ Çakmak’ın 159 vakalık çalışmasında hasta yaş aralığı 19-65 idi. 159 hastanın 116’sı (\%73) kadın, 43’ü (\%27) erkek idi. Yaş ortalaması 32,74 olup bu oran erkeklerde 32,73, kadınlarda 32,74 idi. ${ }^{30}$ Prasad ve ark'.'n çocuklar üzerinde yaptığ 67 vakalık çalışmada hasta-ların 42'si $(\% 62,70)$ erkek ve 25'i $(\% 37,30)$ kadın idi. $^{31}$ Çalışmamızda hem hasta yaş aralığı, hem de hasta cinsiyet oranları Karaahmet' in yaptığı çalışmadaki sonuca çok yakındı.

Hasta yaş ortalaması bizim çalışmamızda Karaahmet'in çalışmasındakinden biraz fazla olup Çakmak’ın çalışmasına göre ise yüksekti.3 Çalışmamızda hasta yaş aralığg Çakmak’ın çalışmasındaki değere çok yakındı. ${ }^{30}$

Dünyada Çölyak hastalığında kadın/erkek oranı 2,8:1'dir.10 Çalışmamızda da kadın üstünlüğü görülmekte olup 54 vakalık çalışmamızda bu oran 2:1 olarak bulundu. Kadınların lehine olmak üzere bu oran Prasad ve ark.'nın 67 vakalık çalışmasında 1,68:1, Karaahmet'in 113 vakalık çalışmasında 2,14:1, Çakmak’in 159 vakalık çalışmasında 2,7:1 olarak bulunmuş olup daha fazla hasta sayısı olan çalışmalarda dünyadaki orana daha çok yaklaşıldığı görülmüştür. 3,30,31

Çalışmamızda hastaların 2'sinde $(\% 3,70)$ evre 1, 5'inde $(\% 9,25)$ evre 2,9 'unda $(\% 16,66)$ evre 3a, 34'ünde $(\% 62,90)$ evre $3 \mathrm{~b}, 4$ 'ünde $(\% 7,40)$ evre $3 \mathrm{c}$ izlendi. Hastalarda evre 0 ve 4 izlenmedi. Karaahmet'in çalışmasında 113 vakanın 13'ünde $(\% 11,50)$ evre 0,27 ' sinde $(\% 23,80)$ evre 1 , 5 'inde $(\% 4,50)$ evre 2,14 ' ünde $(\% 12,40)$ evre $3 a, 38$ 'inde $(\% 33,60)$ evre $3 b, 16$ 'sinda $(\% 14,20)$ evre $3 c$ izlendi.3 Pra- sad ve ark.'nın 67 vakalık bir araştırmasında hastalarda 1., 2 . ve 4. evre izlenmeyip hepsinde 3. evre izlendi. Bunlardan 6'sinda (\%9) evre 3a, 12'sinde (\%17,90) evre 3 b ve 49 'unda (\%73.10) evre 3c izlendi. ${ }^{31}$ Gupta ve ark.'nın bir çalışmasinda 87 hastanın 13'ünde (\%15) evre 1, 10’unda (\%11,50) evre 2, 36'sinda $(\% 41,40)$ evre 3a, 16'sinda $(\% 18,40)$ evre 3 b, 10 'unda $(\% 11,50)$ evre 3c, 2'sinde $(\% 0,23)$ evre 4 izlendi. Gupta ve ark.'nın çalışmasında en çok evre 3a izlenirken, çalışmamızda ve Karaahmet'in çalışmasında benzer şekilde en çok evre 3b, Prasad ve ark.nın çalışmasında ise en çok evre $3 c$ izlendi. ${ }^{3,31,32} \mathrm{Bu}$ sonuçlara göre Çölyak hastalığının en çok 3. evrede teşhis edildiği görülmektedir.

Çölyak hastalığının erken teşhisinin ve uygun tedavisinin hayat kalitesini artıracağından dolayı, özellikle sebebi belirlenemeyen malabsorbsiyon bulguları gibi gastrointestinal sistem ve ağrı başta olmak üzere gastrointestinal sistem dışı şikayetleri olan hastalarda bu şikayetlerin arkasında Çölyak hastalığının bulunabileceğinin göz ardı edilmemesi gerekir. 
Sakarya Tip Dergisi 2020;10(1):37-43

TAYFUR,Erzincan’da 2010-2018'de Ç̈̈lyak Hastalarıın Değerlendirilmesi

\section{Kaynaklar}

1. Theethira TG, Dennis M. Celiac Disease and the Gluten-Free Diet: Consequences and Recommendations for Improvement. Dig Dis 2015;33(2):175-182.

2. Rubio-Tapia A, Hill ID, Kelly CP, Calderwood AH, Murray JA. ACG Clinical Guidelines: Diagnosis and Management of Celiac Disease. Am J Gastroenterol 2018;108(5):656-676.

3. Karaahmet F. Çölyak Hastalı̆̆ında Teşhis Süresi. Length of Diagnosis in Celiac Disease. Ege Tip Dergisi/Ege Journal of Medicine 2018;57(4):228-231.

4. İşleroğlu H, Dirim SN, Ertekin FK. Gluten İ̧̧ermeyen Hububat Esaslt Alternatif Ürün Formülasyonları ve Üretim Teknolojileri. Derleme / Review. GIDA2009;34(1):29-36.

5. Serra S, Jani PA. An Approach to Duodenal Biopsies. J Clin Pathol 2006;59(11):1133-1150.

6. Catassi C, Fabiani E, Corrao G, Renzo A, Carella AM, Gabrielli A et al. Risk of Non-Hodgkin Lymphoma in Celiac Disease. JAMA The Journal of the American Medical Association 2002;287(11):1413-1419.

7. Harris LA, Park JY, Voltaggio L, Lam-Himlin D. Celiac Disease: Clinical, Endoscopic, and Histopathologic Review. Gastrointest Endosc 2012;76(3):625-640.

8. Farell RJ, Kelly CP. Celiac Sprue. New England Journal of Medicine 2002;346(3):180-188.

9. Megiorni F, Mora B, Bonamico M, Barbato M, Nenna R, Maiella G. HLA-DQ and Risk Gradient for Celiac Disease. Hum Immunol 2009;70(1):55-59.

10. Hin H, Bird G, Fisher P, Mahy N, Jewell D. Coeliac Disease in Primary Care: Case Finding Study. BMJ 1999;318(7177):164-167.

11. Holmes GKT, Moor F. To Determine The Age and Gender of Patients With Coeliac Disease 1958-2008 in a Single Centre. Gut 2011;60: Issue Suppl 1.http://dx.doi.org/10.1136/ gut.2011.239301.175

12. Gujral N, Freeman HJ, Thomson ABR. Celiac Disease: Prevalence, Diagnosis, Pathogenesis and Treatment. World J Gastroenterol 2012;18(42):6036-6059.

13. Daniel A. Leffler, Ciaran P. Kelly. Çölyak Hastalığıın Değerlendirilmesi Ve Tanısı İle İlgili Bir Güncelleme. Current Opinion in Allergy and Clinical Immunology 2006; 1(2):69-77.

14. Elsurer R, Tatar G, Șimşek H, Balaban YH, Aydinli M, Sokmensuer C. Celiac Disease in the Turkish Population. Dig Dis Sci 2005;50(1):136-142.

15. Cummins AG, Roberts-Thomson, IC. Prevalence of Celiac Disease in the Asia-Pacific region. Journal of Gastroenterology and Hepatology 2009;24(8):1347-1351.

16. Haubrich WS, Schaffner F, Berk JE (eds). Bockus Gastroenterology, 5th. ed. Philadelphia: WB Saunders; 1995.Chapter 59.p.1027-1046.

17. Bürgin-Wolff A, Gaze H, Hadziselimovic F, Huber H, Lentze MJ, Nusslé D, et al. Antigliadin and Antiendomysium Antibody Determination for Coeliac Disease. Arch Dis Child 1991;66(8):941-947.
18. Sulkanen S, Halttunen T, Laurila K, Kolho KL, Korponay-Szabó IR, Sarnesto A, et al. Tissue Transglutaminase Autoantibody Enzyme-linked Immunosorbent Assay in Detecting Celiac Disease. Gastroenterology 1998;115(6):1322-1328.

19. Husby S, Murray JA, Katzka DA. AGA Clinical Practice Update on Diagnosis and Monitoring of Celiac Disease: Changing Utility of Serology and Histologic Measures: Expert Review. Gastroenterology 2019;156(4):885-889.

20. Dewar D, Pereira SP, Ciclitira PJ. The Pathogenesis of Coeliac Disease. Int J Biochem Cell Biol 2004;36(1):17-24.

21. Rodrigo L. Celiac Disease. World J Gastroenterol 2006;12(41):6577-6584.

22. Dogan IS, Yildiz O, Meral R. Optimization of Corn, Rice and Buck wheat Formulations for Gluten-Free Wafer Production. Food Sci Technol Int 2016;22(5):410-419.

23. Husby S, Bai JC. Follow-up of Celiac Disease. Gastroenterol Clin North Am 2019;48(1):127136.

24. Marsh MN. Gluten, Major Histocompatibility Complex, and the Small Intestine. A Molecular and Immunobiologic Approach to the Spectrum of Gluten Sensitivity (Celiac Sprue) Gastroenterology 1992;102(1):330-354.

25. Oberhuber G, Granditsch G, Vogelsang H. The Histopathology of Coeliac Disease: Time for a Standardized Report Scheme for Pathologists. Eur J Gastroenterol Hepatol 1999;11(10):1185-1194.

26. Corazza GR, Villanacci V. Coeliac Disease. J Clin Pathol 2005;58(6):573-574.

27. Ensari A.Gluten-Sensitive Enteropathy (Celiac Disease): Controversies in Diagnosis and Classification. Arch Pathol Lab Med 2010;134(6),826-836.

28. Taavela J, Kurppa K, Collin P, Lähdeaho ML, Salmi T, Saavalainen P, et al. Degree of Damage to the Small Bowel and Serum Antibody Titers Correlate with Clinical Presentation of Patients with Celiac Disease. Clin Gastroenterol Hepatol 2013;11(2):166-171.

29. Marsh MN, Heal CJ. Review Evolutionary Developments in Interpreting the Gluten-Induced Mucosal Celiac Lesion: An Archimedian Heuristic. Nutrients 2017;9(3):213.

30. Çakmak A. Ankarảa Yaşayan 19-65 Yaş Arası Çölyak Hastalarının Beslenme Durumlarının Yaşam Kalitesi Üzerine Etkisi. Hacettepe Üniversitesi Sağlık Bilimleri Enstitüsü, Diyetetik Programı Yüksek Lisans Tezi, Ankara,2013.s.46-47.

31. Prasad KK, Thapa BR, Nain CK, Singh K. The Frequency of Histologic Lesion Variability of The Duodenal Mucosa in Children With Celiac Disease. World J Pediatr 2010;6(1):60-64.

32. Gupta P, Chhabra S, Singh S, Malhotra P, Sen R. A Study of Clinical, Serological and Histopathological Profile in Celiac Disease. International Journal of Current Research 2016;8(9):39403-39408 